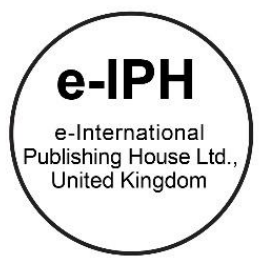

\title{
Evaluating Multi-dimensional Human Needs in Open Spaces: Taman Tasik Shah Alam, Selangor, Malaysia
}

\author{
Dasimah Omar ${ }^{\star}$, Filzani Illia Ibrahim ${ }^{1}$, Nik Hanita Nik Mohamad 2 \\ ${ }^{1}$ Centre of Studies for Town and Regional Planning, Faculty of Architecture, Planning\& Surveying, Universiti Teknologi Mara, Malaysia \\ ${ }^{2}$ Centre of Postgraduate Studies, Faculty of Architecture, Planning \& Surveying, Universiti Teknologi Mara, Malaysia \\ ${ }^{3}$ Centre of Studies for Landscape Architecture, Faculty of Architecture, Planning \& Surveying, Universiti Teknologi Mara, Malaysia
}

\begin{abstract}
The paper aims to provide valuable insight of the various dimensions of human needs' and their perceived benefits towards open spaces. This study employed a mixed method research design involving both quantitative and qualitative methods that were utilised to identify and evaluate the human-human interaction and human-nature interaction in the area of study. Primary data was gathered by using questionnaire survey that administered to 428 respondents as visitors to a public park. The finding of this study is intended to show the main domains that reflect human needs' toward open spaces together with perceived benefits to the open spaces users.
\end{abstract}

(C) 2016. The Authors. Published for AMER ABRA by e-International Publishing House, Ltd., UK. Peer-review under responsibility of AMER (Association of Malaysian Environment-Behaviour Researchers), ABRA (Association of Behavioural Researchers on Asians) and cE-Bs (Centre for Environment-Behaviour Studies), Faculty of Architecture, Planning \& Surveying, Universiti Teknologi MARA, Malaysia.

Keywords: Open spaces; physical health; outdoor urban environment; human interaction

\section{Introduction}

The provision of quality open spaces is vital towards achieving a vibrant and liveable city. Urban open spaces, when given prominence and focus, can achieve the monumentality a form of marker or gesture for the public to engage socially. Our city must invest its future in these spaces by creating all the chances and forms to respond to a public environment. Historically, mankind has created open spaces for various reasons and as such, open spaces are often viewed as the product of a complex society with different societal needs, interest and aesthetics, which evolved over time. Humans' relationship with open spaces is becoming increasingly complex due to the heterogeneous cultural and demographic dimensions of socio-economic, gender, type

${ }^{*}$ Corresponding author. Tel.: +0-603-5544-4294

E-mail address: dasimaho@yahoo.com

(C) 2016. The Authors. Published for AMER ABRA by e-International Publishing House, Ltd., UK. Peer-review under responsibility of AMER (Association of Malaysian Environment-Behaviour Researchers), ABRA (Association of Behavioural Researchers on Asians) and cE-Bs (Centre for Environment-Behaviour Studies), Faculty of Architecture, Planning \& Surveying, Universiti Teknologi MARA,Malaysia.

DOI: https://doi.org/10.21834/e-bpj.v1i2.259 
of activities and park facilities. Also, the growing scarcity of open spaces is of concern to the local authorities as there is a drastic reduction in a good quality open spaces left in the urban areas.

The objectives of this paper are to identify the motives of urban dwellers in visiting open spaces, to examine the humanhuman interaction and human-nature interactions in open spaces, and to determine the perceived benefits of urban dwellers experienced in open spaces. This study employed a mixed method research design involving both quantitative and qualitative methods that were utilised to identify and investigate the human-human interaction and human-nature interaction in the area of study. Primary data was gathered by using questionnaire survey that administered to 428 respondents as visitors to a public park. The findings of this study will show the main domains that reflect human needs towards open spaces together with the perceived benefits to the open spaces users. It is hoped to guide landscape planners and designers in a preferred conducive composition and configuration of human needs towards open spaces.

\section{Human Interaction in Open Spaces}

Open spaces act as a positive channel for people engagement and interaction (Omar, Illia, \& Hanita, 2015). Department of Park and Recreation of New York City stated that open space in the early $20^{\text {th }}$ century began to be used not only for rest and recreation, but also to foster a sense of belonging and community. However, people value the open spaces differently. According to Mutiara \& Isami (2012), urban people prefer their open spaces provided with a variety of recreation activities instead attractive natural areas. Machabee, Oleson, \& Kinzig (2004) then claimed the users of open spaces are based on socio-economic factor, as the residents of high-income neighbourhood tend to use their open spaces more than resident in the middle or low-income area. Taylor (1993) previously claimed that open spaces users are different based on their ages. He added that teenagers at the ages of 16-19 years old were attracted by the aesthetics of the open spaces while the few of the others are more concerned with the feature and valuing maintenance.

According to Rasidi, Jamirsah, \& Said (2012), there is an increasing trend of research regarding on significance of open spaces. The development of recent decades resulting in the loss of forest, farm, forest fringe and other open space lands that somehow contributes to urban residents' quality of life. The growing scarcity of open space is of concern for local authorities since there is an alarming reduction in quality open spaces for urban community's recreational needs (Illia, Omar, \& Hanita, 2013). Rasidi et.al (2012) highlighted the need to maintain quality open spaces as Malaysia is in the quest of providing more urban and suburban landscapes. Hence, several questions to raised in this paper are; Why do people need open spaces? What is the type of interaction they get from visiting open spaces? What are the benefits they get and do these benefits affect their quality of life? These are the main research questions that will be addressed by this paper.

Thus, Matsuoka \& Kaplan, (2008), identified major themes that directly linked to the open spaces including human-nature interaction and human-human interaction. The domains then applied in the study as the general guidelines. Under the nature needs, there are three variables that were measured that is, contact with nature, aesthetic preference, and recreation or play. As for the human needs, the variables to be measured are social interaction, citizen participation, and the sense of community. Table 1 below shows the framework.

Table 1. Theoretical framework of human interaction in open spaces (Matsuoka \& Kaplan, 2008).

\begin{tabular}{|c|c|c|c|c|c|c|c|}
\hline \multirow[t]{2}{*}{ Author } & \multicolumn{3}{|c|}{ Nature needs } & \multicolumn{3}{|c|}{ Human needs } & \multirow{2}{*}{$\begin{array}{l}\text { Primary Data } \\
\text { Quantitative/ } \\
\text { Qualitative Data }\end{array}$} \\
\hline & $\begin{array}{l}\text { Contact } \\
\text { with } \\
\text { nature }\end{array}$ & $\begin{array}{l}\text { Aesthetic } \\
\text { Preference }\end{array}$ & $\begin{array}{l}\text { Recreation/ } \\
\text { play }\end{array}$ & $\begin{array}{l}\text { Social } \\
\text { interaction/ } \\
\text { privacy }\end{array}$ & $\begin{array}{l}\text { Citizen } \\
\text { Participation }\end{array}$ & $\begin{array}{l}\text { Sense of } \\
\text { Community }\end{array}$ & \\
\hline Austin (2004) & $\bullet$ & & & $\bullet$ & & $\bullet$ & Qualitative \\
\hline Chiesura (2004) & $\bullet$ & & $\bullet$ & $\bullet$ & $\bullet$ & & Quantitative \\
\hline Gobster (2001) & $\bullet$ & $\bullet$ & $\bullet$ & & $\bullet$ & $\bullet$ & Both \\
\hline Oguz (2000) & $\bullet$ & $\bullet$ & $\bullet$ & $\bullet$ & & & Qualitative \\
\hline Ozguner and & - & - & & - & & & Quantitative \\
\hline
\end{tabular}




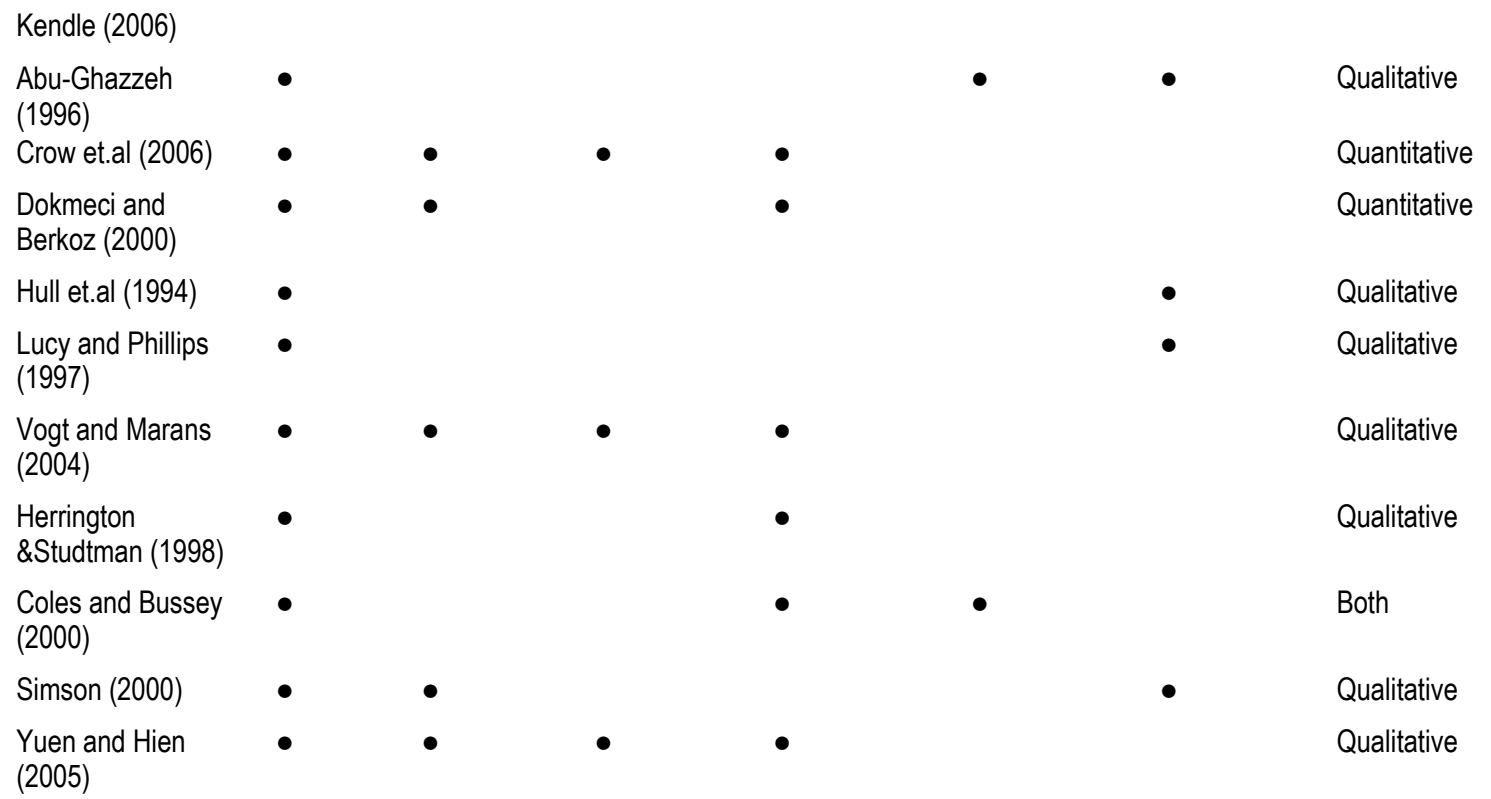

\section{Research Methodology}

\subsection{Variables measured}

This research explores multi-dimensional human needs in open spaces and the perceived benefits from the interactions towards the area. The design of the spatial configuration could serve as a platform for human-nature interaction or humanhuman interaction. In order to comprehend design qualities that encourages interactions, it is recommended to measure the open spaces properties (i.e green quality, green setting, accessibility, facilities and amenities) and interactions (human-nature interaction and human-human interaction) of the open space through documented responses. The unit of analysis is the various range of age group of the open spaces in Shah Alam Lake Garden, Selangor. The approach in dividing the variables into two major categories was for the purpose of systematic data collection and to gauge how daily usage pattern of open spaces related to the interactions.

\subsection{Methods for data collection}

A total of 500 of survey questionnaires were distributed within the Shah Alam Lake Garden, Selangor. It was distributed randomly regardless the users' age, race and ethnicity. However, only 428 reliable respondents were taken for further analysis as the other 72 respondents left the questionnaires blank. The unanswered survey form considered as incomprehensible, undecided and ignored. In this survey, respondents were provided with a survey form with few subsections to determine their level of background, such as gender, income, companionship, mode of transportation to the open spaces, frequency of visits and time spend per visits. Apart from that, the respondents also were asked their main purposes of coming to the open spaces that are divided into two subsections that are the human-nature interaction or human-human interaction.

\subsection{Study area}

The selected study area is Taman Tasik Shah Alam, Selangor Darul Ehsan, Malaysia. Taman Tasik Shah Alam serves the local communities as the urban park of Shah Alam. It functions as one of the favorite retreat of the residents in the vicinity in the evening and during the weekends. It comprises a man-made lake with beautiful landscape in the middle of the city center of Shah Alam. Taman Tasik Shah Alam can be divided into three sections namely the east, the west and the central. The east section is called Tasik Damai whereby the west section is called Tasik Permai. As for the middle section is called Tasik Indah. All 
of the three sections surrounded by beautiful gardens that are ideal for family outing and picnic. The total are for this urban park is 43 hectares with well-built raised platform at certain sections of the lake for the users to enjoy the nature and water habitat surrounding the area. There are some facilities that are available within the vicinity of the lake that could cater for both young and old. It includes a water theme park called Wet World Shah Alam, a floating seafood restaurant that serves Malaysian cuisine, children playgrounds, benches and kayak for rent facility. The urban park also seasonally hosts numerous events including international events such as the annual International Orchid Exhibition and the International Boat Show. The map of Taman Tasik Shah Alam provided in Figure 1 below.

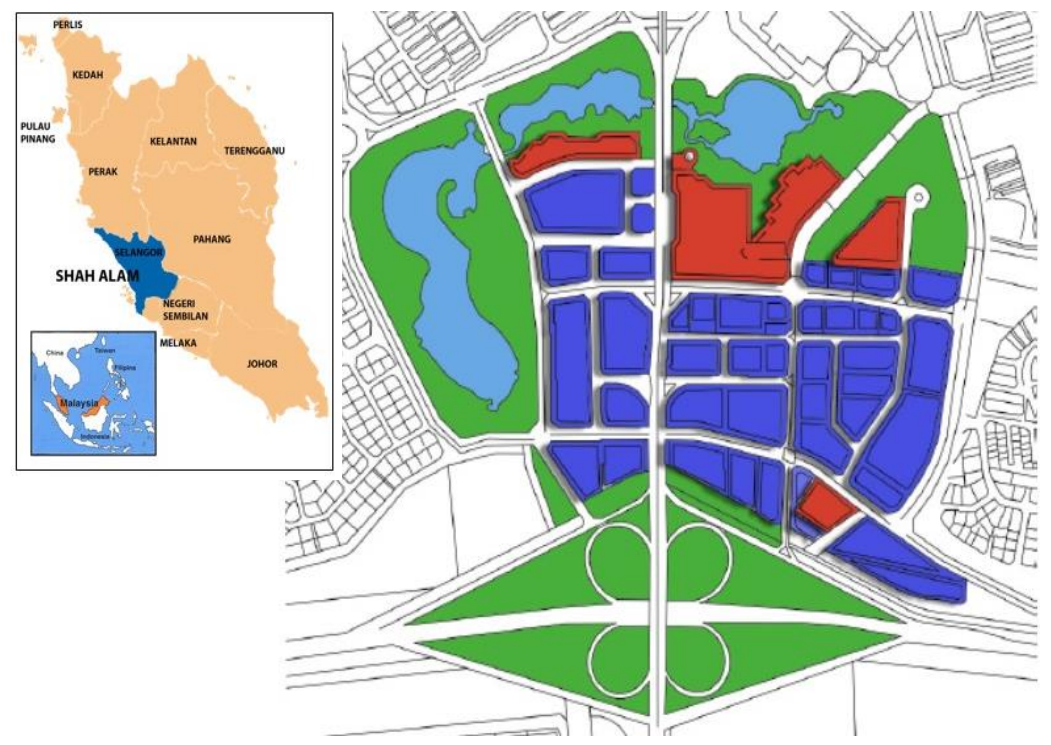

Fig. 1. Site of Taman Tasik Shah Alam

\subsection{Development of the instruments and procedures}

The research instrument was developed based on the literature analysis as well as the items tested on multi-dimensional human needs. Various useable items from human needs pattern studies were integrated to develop further the methods. Every measurement were structured using 5-level Likert Scale that are 1: Strongly Disagree; 2: Disagree; 3: Neutral, 4: Agree and 5: Strongly Agree.

\section{Result and Findings}

The data from survey questionnaires coded into SPSS software for statistical analysis. The main focused this analysis is to understand the relationship of human-human interactions and human-nature interactions that took place in the open spaces area. Demographic attributes such as users' gender, race, age group, and home distance to open spaces also considered. The descriptive analysis in Table 2 provides a cross-tabulation analysis of the frequency by genders, which involved in activities.

Table 2. Descriptive findings of personal and visit information of the respondents in Taman Tasik Shah Alam

\begin{tabular}{lllllll}
\hline $\begin{array}{l}\text { Descriptive Findings } \\
\text { Categories }\end{array}$ & \multirow{2}{*}{$\begin{array}{l}\text { Variable Measured } \\
\end{array}$} & & \multicolumn{3}{c}{ Gender } & \multicolumn{3}{l}{ N=428 } \\
& & & Male & Female & All & $\%$ \\
\hline Personal Information & Age Group & 13-19 years old & 45 & 26 & 71 & 16.6 \\
& & $20-50$ years old & 133 & 198 & 331 & 77.3
\end{tabular}




\begin{tabular}{|c|c|c|c|c|c|}
\hline & $50-60$ years old & 14 & 8 & 22 & 5.1 \\
\hline & 60 years and above & 0 & 4 & 4 & .9 \\
\hline \multirow[t]{2}{*}{ Marital Status } & $\begin{array}{l}\text { Single } \\
\text { Married }\end{array}$ & $\begin{array}{l}139 \\
53\end{array}$ & $\begin{array}{l}125 \\
108\end{array}$ & $\begin{array}{l}264 \\
161\end{array}$ & $\begin{array}{l}61.7 \\
37.6\end{array}$ \\
\hline & Divorce & 0 & 2 & 2 & .5 \\
\hline \multirow[t]{2}{*}{ Nearby } & Yes & 103 & 77 & 180 & 42.1 \\
\hline & No & 89 & 159 & 248 & 57.9 \\
\hline \multirow[t]{4}{*}{ Come from } & Home & 116 & 156 & 272 & 63.6 \\
\hline & College or school & 61 & 51 & 112 & 26.2 \\
\hline & Office & 8 & 15 & 23 & 5.4 \\
\hline & Others & 7 & 14 & 21 & 4.9 \\
\hline \multirow[t]{4}{*}{ Range } & Less than $1 \mathrm{~km}$ & 29 & 14 & 43 & 10 \\
\hline & $1 \mathrm{~km}-2 \mathrm{~km}$ & 26 & 74 & 100 & 23.4 \\
\hline & $2 \mathrm{~km}-5 \mathrm{~km}$ & 81 & 52 & 133 & 31.1 \\
\hline & More than $5 \mathrm{~km}$ & 56 & 96 & 152 & 35.5 \\
\hline \multirow[t]{4}{*}{ Job } & Government & 24 & 50 & 74 & 17.3 \\
\hline & Private & 38 & 63 & 101 & 23.6 \\
\hline & Student & 120 & 102 & 222 & 51.9 \\
\hline & Others & 10 & 21 & 31 & 7.2 \\
\hline \multirow[t]{4}{*}{ Race } & Malay & 173 & 223 & 396 & 92.5 \\
\hline & Chinese & 9 & 4 & 13 & 3.0 \\
\hline & Indian & 10 & 7 & 17 & 4.0 \\
\hline & Others & 0 & 2 & 2 & .5 \\
\hline
\end{tabular}

\subsection{Frequency of visits}

The respondents also asked on their frequency of visitations to Taman Tasik Shah Alam. Approximately $10 \%$ ( $n=43$ ) of the park users use the park for the first time. About 50.7\% ( $n=217)$ visited Taman Tasik Shah Alam at least once a week. 23.4\% $(n=100)$ visited the park at least twice a week. Whereby $4.4 \%(n=19)$ visited the park three times a week. Only $11.4 \%(n=49)$ of respondents using Taman Tasik Shah Alam more than three times in a week.

\subsection{Length of visits}

Approximately half or $49.1 \%(n=210)$ of Taman Tasik Shah Alam users were identified to be using the open spaces within 10 30 minutes time. About $35.5 \%$ ( $n=152$ ) use the open spaces between 30 minutes to 1 hour. Whereby $11.9 \%(n=51)$ users use the open spaces for more than an hour of time. 3.5\% $(n=15)$ of respondents only visited Taman Tasik Shah Alam for a short duration of time; that is less than 10 minutes.

\subsection{Purpose of using open spaces}

The respondents were being asked about their purpose of using the open spaces that divided into two major themes that are human-nature interaction and human-human interaction. As for the human-human interaction subthemes, it includes social interaction and privacy, citizen participation, and community events. The result is in Table 3. 
Table 3. Overall percentage of respondents' purposes to Taman Tasik Shah Alam

\begin{tabular}{lllllll}
\hline & \multicolumn{3}{l}{ Human-Nature Interaction } & \multicolumn{3}{l}{ Human-Human Interaction } \\
\hline & $\begin{array}{l}\text { Contact with } \\
\text { nature }\end{array}$ & $\begin{array}{l}\text { Aesthetic } \\
\text { Preference }\end{array}$ & $\begin{array}{l}\text { Recreational } \\
\text { Purposes }\end{array}$ & $\begin{array}{l}\text { Social } \\
\text { Interaction }\end{array}$ & $\begin{array}{l}\text { Citizen } \\
\text { Participation }\end{array}$ & $\begin{array}{l}\text { Community } \\
\text { Events }\end{array}$ \\
\hline Yes & 274 & 90 & 305 & 193 & 34 & 39 \\
Percentage & 64.0 & 21.0 & 71.3 & 45.1 & 7.9 & 9.1 \\
\hline No & 154 & 338 & 123 & 235 & 394 & 389 \\
Percentage & 36.0 & 79.0 & 28.7 & 54.9 & 92.1 & 90.9 \\
\hline Total (n) & 428 & 428 & 428 & 428 & 428 & 428 \\
Total Percentage & 100 & 100 & 100 & 100 & 100 & 100 \\
\hline
\end{tabular}

Table 3, it can be seen that the highest percentage of respondents coming to Taman Tasik Shah Alam is for recreational purposes $(71.3 \%)$ with the total number of 305 people. It is followed by contact with nature (64\%) with the total number of 274 respondents, social interaction (45.1\%) with total respondents of 193 , aesthetic preference $(21 \%)$ with 90 respondents, community events (9.1\%) with 39 respondents and lastly, citizen participation (7.9\%) with the total number of respondents 34 .

\subsection{Human-nature interaction}

As for the human-nature interaction that they experienced in Taman Tasik Shah Alam, the structure of the questionnaire divided into three sections that are contact with nature, aesthetic preference and recreational play. The result analysed in SPSS, and the analysis using Chi-square and $p$-value methods were applied.

- Contact with Nature

In Table 4 below shows the overall result interpretation of contact with nature towards the area. The respondents' perception of the design, natural appearances, feelings, activities, appreciation and overall. At $5 \%$ level of significant, $p$-value $>0.05$. Null Hypothesis not rejected. There is no relationship between contact with nature and all of the elements. Figure 2 shows the images of contact with nature occurred at the study area

Table 4. Overall analysis for contact with nature

\begin{tabular}{llll}
\hline & Chi-square & df & p-value \\
\hline The design of the open spaces allows me to contact with nature & 2.685 & 4 & 0.6119 \\
I like the natural appearance of the open space & 1.008 & 4 & 0.9085 \\
I feel calm with the nature provided in the open spaces & 0.853 & 3 & 0.8369 \\
I can pursue many activities with nature in this open spaces & 8.438 & 4 & 0.0768 \\
I can appreciate the nature when I'm in the open space & 7.269 & 4 & 0.1223 \\
Overall, I would rate the nature in this open space as very satisfying. & 4.096 & 4 & 0.3931 \\
\hline
\end{tabular}



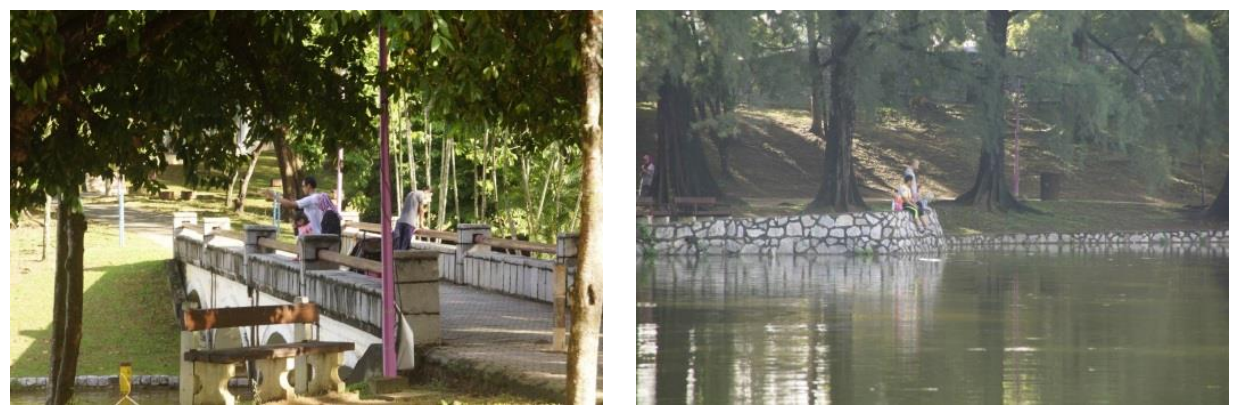

Fig.2. Images of contact with nature

\section{- Aesthetic Preference}

As for aesthetic preference, in Table 5 below shows the overall result interpretation of aesthetic preference towards the area. The respondents asked about the value, natural preferences, feelings, activities and overall. At $5 \%$ level of significant, $p$-value > 0.05. Null Hypothesis not rejected. There is no relationship between aesthetic preference and all of the elements.

Table 5. Overall analysis for aesthetic preference

\begin{tabular}{llll}
\hline & Chi-square & df & p-value \\
\hline The open space allows me to value aesthetic elements & 6.488 & 4 & 0.1656 \\
I like the natural preference in this open space & 1.604 & 4 & 0.8080 \\
I feel calm with the aesthetic elements provided in the open space & 3.131 & 4 & 0.5362 \\
I can pursue many activities in relation with aesthetic element in this open space & 0.960 & 4 & 0.9159 \\
I can appreciate the aesthetic elements when I'm in the open space & 9.203 & 4 & 0.0562 \\
Overall, I would rate the aesthetic preference in this open space as very satisfying. & 6.393 & 4 & 0.1717 \\
\hline
\end{tabular}

\section{- Recreation and Play}

For recreation and play, in Table 6 shows the overall result interpretation of the elements towards Taman Tasik Shah Alam. At $5 \%$ level of significant, $p$-value $>0.05$. Null Hypothesis not rejected. There is no relationship between recreation and all of the elements. Figure 3 shows the images of recreation and play occurred in the study area.

Table 6. Overall analysis for recreation and play

\begin{tabular}{llll}
\hline & Chi-square & df & p-value \\
\hline The open spaces allow me to have recreational activities & 5.372 & 4 & 0.2513 \\
The open spaces provide various activities for recreational purposes & 3.772 & 4 & 0.4377 \\
I feel calm when doing recreational activities here & 3.368 & 4 & 0.4982 \\
I can pursue many physical activities in this open spaces & 2.366 & 4 & 0.6688 \\
There are various of facilities provided in the open spaces for recreational activities & 4.039 & 4 & 0.4008 \\
I normally do recreational activities here alone & 4.141 & 4 & 0.3873 \\
I normally do recreational activities here with my partner/group & 3.383 & 4 & 0.4960 \\
Overall, I would rate the recreational activities provided in the open space as very satisfying & 4.685 & 4 & 0.3212 \\
\hline
\end{tabular}



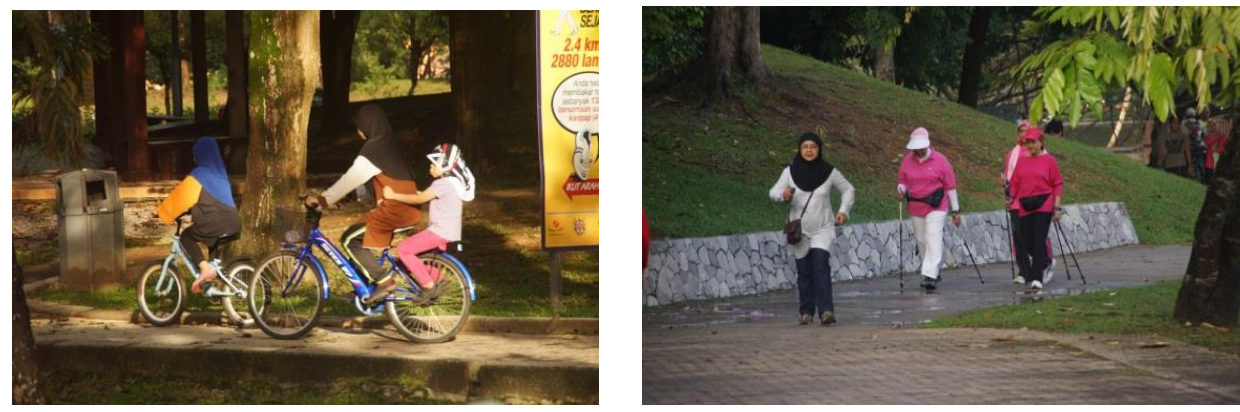

Fig.3. Images of recreation and play

\subsection{Human-human interaction}

As for the human-human interaction that they experienced in Taman Tasik Shah Alam, the structure of the questionnaire divided into three sections that are social interaction, citizen participation, and a sense of community towards the open spaces. The result then analysed in SPSS, and the Chi-square and p-value were identified to proof the null hypothesis.

- Social Interaction

For social interaction, in Table 7 shows the overall result interpretation of the elements towards Taman Tasik Shah Alam. At $5 \%$ level of significant, $p$-value $>0.05$. Null Hypothesis not rejected. There is no relationship between recreation and all of the elements.

Table 7. Overall analysis for social interaction

\begin{tabular}{llll}
\hline & Chi-square & df & $\mathbf{p}$-value \\
\hline I always come here for social interaction with my friends & 5.889 & 4 & 0.2076 \\
The open space is a suitable place for social interaction & 3.366 & 4 & 0.4986 \\
I can pursue many social activities in this open space & 3.749 & 4 & 0.4410 \\
I feel happy doing social interaction in this open space & 2.175 & 4 & 0.7036 \\
The design of the open space allows me to have social interaction easily with my friends & 1.640 & 4 & 0.8017 \\
Overall, I would rate the open space with social interaction activities as very satisfying & 2.371 & 4 & 0.6679 \\
\hline
\end{tabular}

- Citizen Participation

For citizen participation, in Table 8 shows the overall result interpretation of the elements towards Taman Tasik Shah Alam. At $5 \%$ level of significant, $p$-value $>0.05$. Null Hypothesis not rejected. There is no relationship between citizen participation and other elements. However, at $5 \%$ level of significant, Chi-square value $=9.498, p$-value $=0.0498<0.05$. The null hypothesis rejected. There is a relationship between citizen participation and the open space strengthen the citizen participation regardless activities and events held here. Apart from that, at $5 \%$ level of significant, Chi-square value $=10.785, p$-value $=0.0291<0.05$. The null hypothesis rejected. There is a relationship between citizen participation, and the citizens here concern on what is happening in the open space area.

Table 8. Overall analysis of citizen participation

\begin{tabular}{llll}
\hline & Chi-square & df & p-value \\
\hline The open space allows me to socialize with another citizen & 4.734 & 4 & 0.3157 \\
The open space is suitable for citizen participation in the community & 0.964 & 4 & 0.9153 \\
The open space strengthens the citizen participation regardless activities and events held here & 9.498 & 4 & 0.0498 \\
The citizens here concern on what is happening in the open space area & 10.785 & 4 & 0.0291 \\
Overall, I would rate the citizen participation in this open space as very satisfying. & 6.417 & 4 & 0.1701 \\
\hline
\end{tabular}


- Sense of Community

For social interaction, in Table 9 shows the overall result interpretation of the sense of community towards Taman Tasik Shah Alam. At $5 \%$ level of significant, p-value $>0.05$. Null Hypothesis not rejected. There is no relationship between sense of community and all of the elements.

Table 9. Overall analysis for sense of community

\begin{tabular}{llll}
\hline & Chi-square & df & p-value \\
\hline The open space allows me to have community events & 2.811 & 4 & 0.5899 \\
The open space allows me to know the surrounding citizens of the area & 1.118 & 4 & 0.8914 \\
The open space strengthens the relationship between the citizens here & 2.562 & 4 & 0.6336 \\
I feel safe while using the open space & 2.477 & 4 & 0.6488 \\
I know well other people who are using the open space & 2.335 & 4 & 0.6744 \\
The community here know and fully utilized the open space & 0.873 & 4 & 0.9285 \\
Overall, I would rate the sense of community in relation with open space here as very satisfying. & 0.770 & 4 & 0.9424 \\
\hline
\end{tabular}

\section{Perceived Benefits about Open Spaces}

For the perceived benefits in relation to the open spaces, the variables that represent the items by overall perception of human-human interaction, overall perception of human-nature interaction and average perceived benefits are created by using the regression model to test whether these variables can significantly affect the perceived benefits. Hence, the regression proposed model can be seen in Figure 4 below. The result interpretation applied to the proposed model in Table 10.

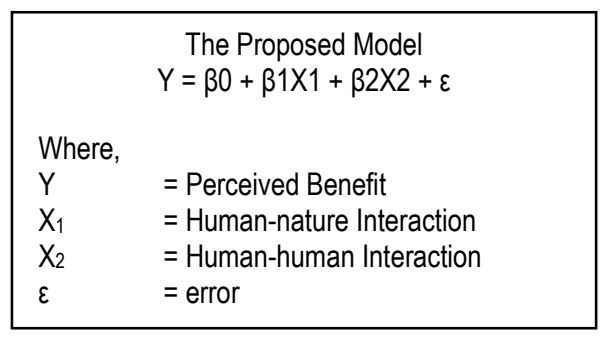

Fig. 4. The proposed model

Table 10. Overall analysis for the proposed model of perceived benefits

\begin{tabular}{|c|c|c|c|c|c|}
\hline \multirow{2}{*}{\multicolumn{2}{|c|}{ Model }} & \multicolumn{2}{|c|}{ Unstandardized Coefficients } & \multirow{2}{*}{$\begin{array}{l}\text { Standardized Coefficients } \\
\text { Beta }\end{array}$} & \multirow{2}{*}{ Sig. } \\
\hline & & $B$ & Std. Error & & \\
\hline & (Constant) & 1.262 & .221 & & .000 \\
\hline \multirow[t]{3}{*}{1} & Human_nature & .418 & .065 & .383 & .000 \\
\hline & Human_human & .222 & .054 & .246 & .000 \\
\hline & $\begin{array}{l}\text { ependent Variab } \\
\text { ?-square }=0.301 \\
\text { statistics }=56.47\end{array}$ & $\begin{array}{l}\text { Benefi } \\
.000\end{array}$ & & & \\
\hline
\end{tabular}


With $\mathrm{R}$-squared value $=0.301$, it shows that $30.1 \%$ of the variation in the perceived benefit can be accounted by variation of independent variables. On the other hand, the F-statistics $=56.474$ and $p$-value $=0.000$ indicate the model is a good fit for the data. In conclusion, based on the model, at $5 \%$ level of significance, both human-nature interaction and human-human interaction do have a significant effect on perceived benefit. All these variables are having a positive impact on perceived benefit.

\section{Conclusions}

In conclusion, this study has shown that the open space is vital to the city sustainability. Human interactions are important to the open spaces as both elements respond well to each other. Apart from that, this study has indicated that nature and human interactions needs elements of open spaces such as the green spaces, water elements, physical attributes to enhance the interactions between human-human and human-nature. Further studies about this study are recommended to ensure for ensuring the city's sustainability.

\section{Acknowledgements}

The authors would like to thank all officers of Research Management Institute of Universiti Teknologi MARA particularly whom in charge for this research grant. This research funded by Fundamental Research Grant Scheme (FRGS) from Ministry of Higher Education, Malaysia. Special acknowledgments to the co-researchers in supporting the success of this research.

\section{References}

Chiesura, A. (2004). The role of urban parks for the sustainable city. Landscape and Urban Planning, 68(1), 129-138. doi:10.1016/j.landurbplan.2003.08.003.

Department of Town and Country Planning, Selangor (2004). National Physical Plan. Ministry of Housing and Local Government Malaysia, Malaysia.

Illia, F., Omar, D., \& Hanita, N. (2013). Human interaction in open spaces, (December), 17-18.

Illia, F., Omar, D., \& Hanita, N. (2014). Theoretical review on sustainable city indicators in Malaysia, 04.

Marzukhi, M. A., Karim, H. A., \& Latfi, M. F. (2012). Evaluating the Shah Alam City Council Policy and Guidelines on the hierarchy of neighborhood open space. Procedia - Social and Behavioral Sciences, 36(June 2011), 456-465. doi:10.1016/j.sbspro.2012.03.050

Machabee, L. G., Oleson, J. J., Kinzig, A. P. (2005). Neighborhood parks uses by phoenix residents: An exploration of socio demographic differences. People, Places, and Parks: Proceedings of the 2005 George Wright Society Conference on Parks, Protected Areas and Cultural Sites. Hancock, Michigan: The George Wright Society.

Matsuoka, R. H., \& Kaplan, R. (2008). People needs in the urban landscape : Analysis of landscape and urban planning contributions, 84, 7-19. doi:10.1016/j.landurbplan.2007.09.009.

Mutiara, S., \& Isami, K. (2012). Characteristic of public small park usage in Asia Pacific Countries : Case study in Jakarta and Yokohama City, 35(December 2011), 412-419. doi:10.1016/j.sbspro.2012.02.106.

Omar, D., Illia, F., \& Hanita, N. (2015). Human interaction in open spaces, 01, 1-9.

Philips, L.E., (1996). Parks: design and management,United States of America: McGrawHill.

Rasidi, M. H., Jamirsah, N., \& Said, I. (2012). Urban green space design affects urban residents' social interaction. Procedia - Social and Behavioral Sciences, 68(November), 464-480. doi:10.1016/j.sbspro.2012.12.242.

Shuib, K.B. (2008). Context, concept and purpose of park and protected areas, Shah Alam: Recreational Park Planning. 